NASA Technical Memorandum 106557

\title{
Room-Temperature Synthesis of $\mathrm{CuInQ}_{2}$ $(\mathrm{Q}=\mathrm{S}$ or $\mathrm{Se})$ in Non-Aqueous Solution Using an Organoindium Reagent
}

Aloysius F. Hepp and Maria T. Andras

Lewis Research Center

Cleveland, Ohio

Christopher C. Landry and Andrew R. Barron

Harvard University

Cambridge, Massachusetts

Prepared for the

Fall Meeting

sponsored by the Materials Research Society

Boston, Massachusetts, November 29-December 3, 1993

National Aeronautics and

Space Administration 


\title{
ROOM-TEMPERATURE SYNTHESIS OF $\mathrm{CuInQ}_{2}(\mathrm{Q}=\mathrm{S}$ or $\mathrm{Se})$ IN NON-AQUEOUS SOLUTION USING AN ORGANOINDIUM REAGENT
}

\author{
ALOYSIUS F. HEPP, ${ }^{*}$ MARIA T. ANDRAS, ${ }^{*}, \ddagger$ CHRISTOPHER C. LANDRY, ${ }^{* *}$ AND \\ ANDREW R. BARRON** \\ *NASA Lewis Research Center, M.S. 302-1, Cleveland, OH $44135^{* *}$ Department of Chemistry, \\ Harvard University, Cambridge, MA 02138
}

\begin{abstract}
We have discovered a novel two-phase synthesis of $\mathrm{CuInSe}_{2}$ at $25^{\circ} \mathrm{C}$ from $\mathrm{Cu}_{2} \mathrm{Se}$ and $\left(\mathrm{C}_{5} \mathrm{H}_{5}\right)_{3} \mathrm{In}$ in 4-methylpyridine (4-MePy). An analogous reaction to produce $\mathrm{CuInS}_{2}$ must be run at $140{ }^{\circ} \mathrm{C}$ in refluxing 4-MePy in the presence of 2-mercaptopyridine. Microscopy of $\mathrm{CuInSe} 2$ produced at $25^{\circ} \mathrm{C}$ shows it to be platelet-shaped crystallites with an approximate particle size of 10 microns, less than $2 \% \mathrm{C}$ and $\mathrm{H}$, with a small amount of unidentified crystalline impurity. Our results demonstrate that it is possible to produce from solution a material that is ordinarily synthesized in bulk or films at much higher temperatures or using extraneous reagents and/or electrons.
\end{abstract}

\section{INTRODUCTION}

The very high radiation tolerance [1], high absorption coefficient, and low cost of deposition of polycrystalline $\mathrm{CuInQ}_{2}(\mathrm{Q}=\mathrm{S}$ or $\mathrm{Se}, \mathrm{CIS})$ and related chalcopyrite semiconductors make this class of materials ideal for thin-film solar cell arrays [2-4]. Another important variable to consider for space applications is the total array mass or power-to-weight ratio [5]. Indeed, the potential for low-cost, high power-to-weight ratio, radiation resistant solar arrays has led to a renewed interest in chalcopyrite semiconductors [6-9]. While considerable savings can be achieved by using thin films for the energy conversion portion of a solar cell, a significant fraction of the mass of a solar cell array is taken up by the substrate. At this point, state-of-the-art CIS solar cells are deposited on Mo-coated glass substrates [2,6,7]. Therefore, to progress further in the achievement of higher power-to-weight ratios, it is essential to consider other substrates.

One potentially useful substrate for CIS solar cells are polymers such as polyimides. The high temperatures of physical deposition techniques precludes the use of polymers in conventional processing. To this end, we have embarked on a research program to produce films of CIS at low temperatures using chemical precursors. Because stoichiometry control is very important in producing high-quality devices [10], a molecular-engineering approach should allow for greater control in the synthesis of a desired stoichiometry. Added benefits from this process include use of less hazardous materials in the production process [11] and a simple manufacturing process that may prove important in future in-situ manufacturing of power systems for space applications [12]. We report a novel two-phase room-temperature synthesis of CIS that we have discovered recently in the course of our research program. We also discuss the impact of our results on the design of potential precursors for CIS solar cells.

\section{EXPERIMENTAL}

Cuprous selenide ( $\left.\mathrm{Cu}_{2} \mathrm{Se}, \mathrm{Alfa}\right)$ and 2-mercaptopyridine $\left(\mathrm{C}_{5} \mathrm{H}_{4}(\mathrm{SH}) \mathrm{N}(2-\mathrm{SH}-\mathrm{Py})\right.$, Aldrich) were used without further purification. Triscyclopentadienylindium(III) $\left(\left(\mathrm{C}_{5} \mathrm{H}_{5}\right)_{3} \mathrm{In}\right)$ was prepared according to literature methods [13]. Scanning electron microscopy (SEM) was done on a Hitachi S 800 microscope. X-ray diffraction (XRD) data was collected using monochromated $\mathrm{Cu} \mathrm{K} \mathrm{K}_{\alpha}$ radiation on a Scintag PAD V and a Philips APD diffractometer. Further details are given in an earlier report of this work [14].

¥ - National Research Council/NASA Lewis Research Center Resident Research Associate. 


\section{RESULTS AND DISCUSSION}

A mixture of $\left.\mathrm{C}_{5} \mathrm{H}_{5}\right)_{3} \mathrm{In}(0.17 \mathrm{~g}, 0.548 \mathrm{mmol})$ and $\mathrm{Cu}_{2} \mathrm{Se}(0.20 \mathrm{~g}, 0.9706 \mathrm{mmol})$ in $15 \mathrm{ml}$ of 4-methylpyridine $\left(\mathrm{C}_{5} \mathrm{H}_{4} \mathrm{CH}_{3} \mathrm{~N}, 4-\mathrm{MePy}\right)$ was stirred for five days at $25^{\circ} \mathrm{C}$. During this time, the solution gradually changed from faint pink to dark purple. The mixture was filtered and the resulting black solid was dried under vacuum for 14 hours yielding $0.07 \mathrm{~g}$ of product. Elemental analysis showed the material to have less than two percent carbon and hydrogen [14]. The $\mathrm{Cu} / \mathrm{In}$ ratio for samples produced is a function of the $\left(\mathrm{C}_{5} \mathrm{H}_{5}\right)_{3} \mathrm{In}$ to $\mathrm{Cu}_{2} \mathrm{Se}$ ratio; this is currently under study and will be reported in a full paper. A comparison between an XRD powder pattern of the material obtained at $25^{\circ} \mathrm{C}$ and a reference sample obtained from Johnson Matthey is shown in Fig. 1.

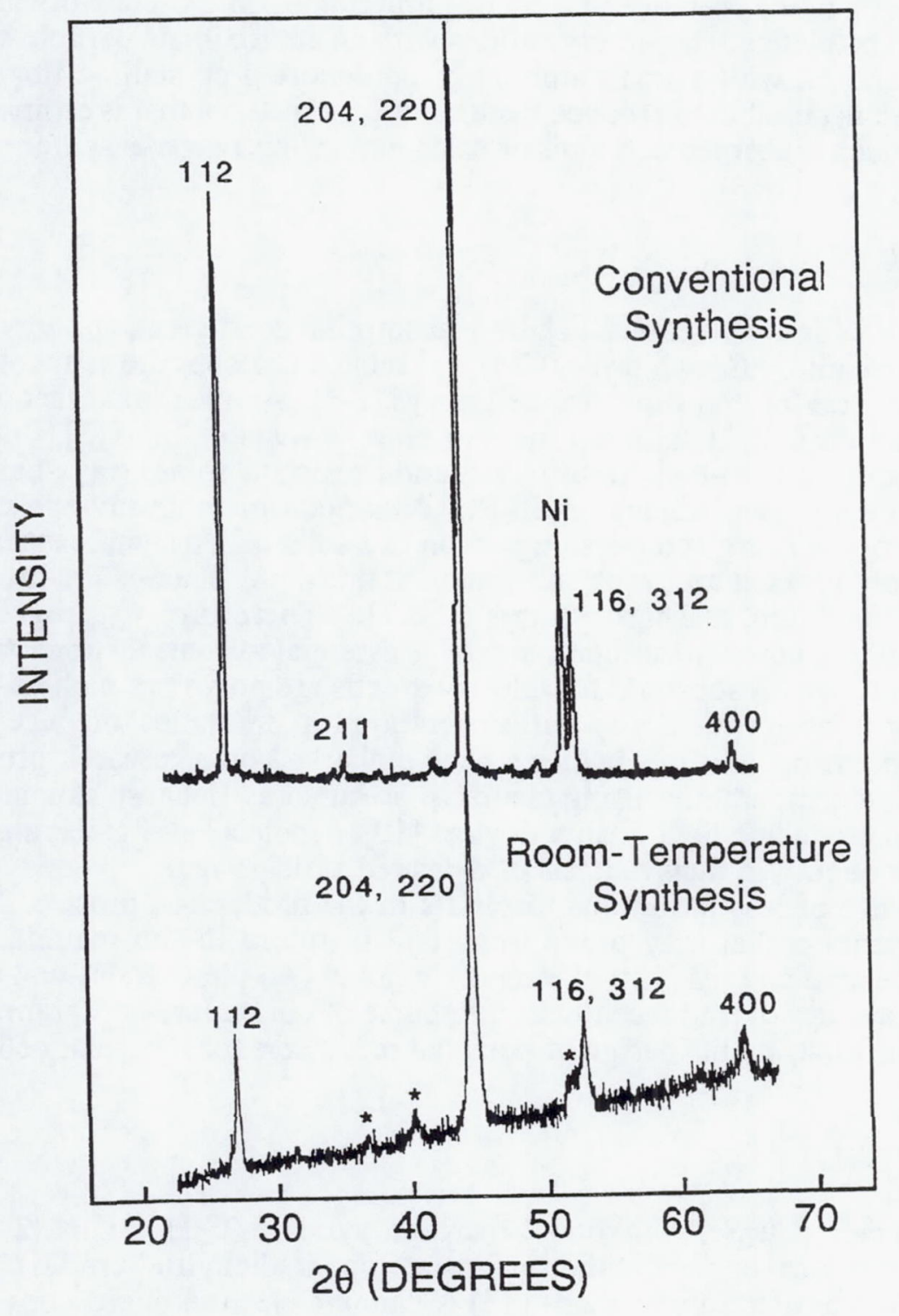

Figure 1. Comparison of X-ray diffraction powder patterns for reference sample of CuInSe2 (with a Ni X-ray standard) and sample (R9) produced at room temperature from $\mathrm{Cu}_{2} \mathrm{Se}$ and $\left(\mathrm{C}_{5} \mathrm{H}_{5}\right)_{3} \mathrm{In}$ in 4-methylpyridine. JC-PDS file 23-209 used to identify peaks [11]. Peaks noted with asterisk could not be matched to any known copper- or indium-containing powder pattem. 
The main points of interest are: (1) the low level of crystalline impurity(ies) detected by $\mathrm{XRD}$; (2) the presence of all the major diffraction peaks found for a reference sample of $\mathrm{CuInSe} 2$; and (3) the polycrystalline nature of the material produced at $25^{\circ} \mathrm{C}$. Our XRD data is consistent with the chalcopyrite phase, the phase used for electronic devices [2]. Typical morphology of the material produced at room temperature is seen in SEM micrographs (Fig. 2).

The crystallites have a range of size from 5 to 20 microns with a mode of $\sim 10 \mu \mathrm{m}$. Another feature of the material is the platelet morphology of the particles, this may account for the difference in the intensity ratio of the diffraction peaks in Fig. 1 as compared to the reference sample with more isotropic crystallites. It is not clear from our data whether the particles are single crystals; as XRD detects only crystalline material, amorphous impurities would be undetected. Current efforts are being directed to a more exhaustive chemical analysis of product materials and will be included in a future report.
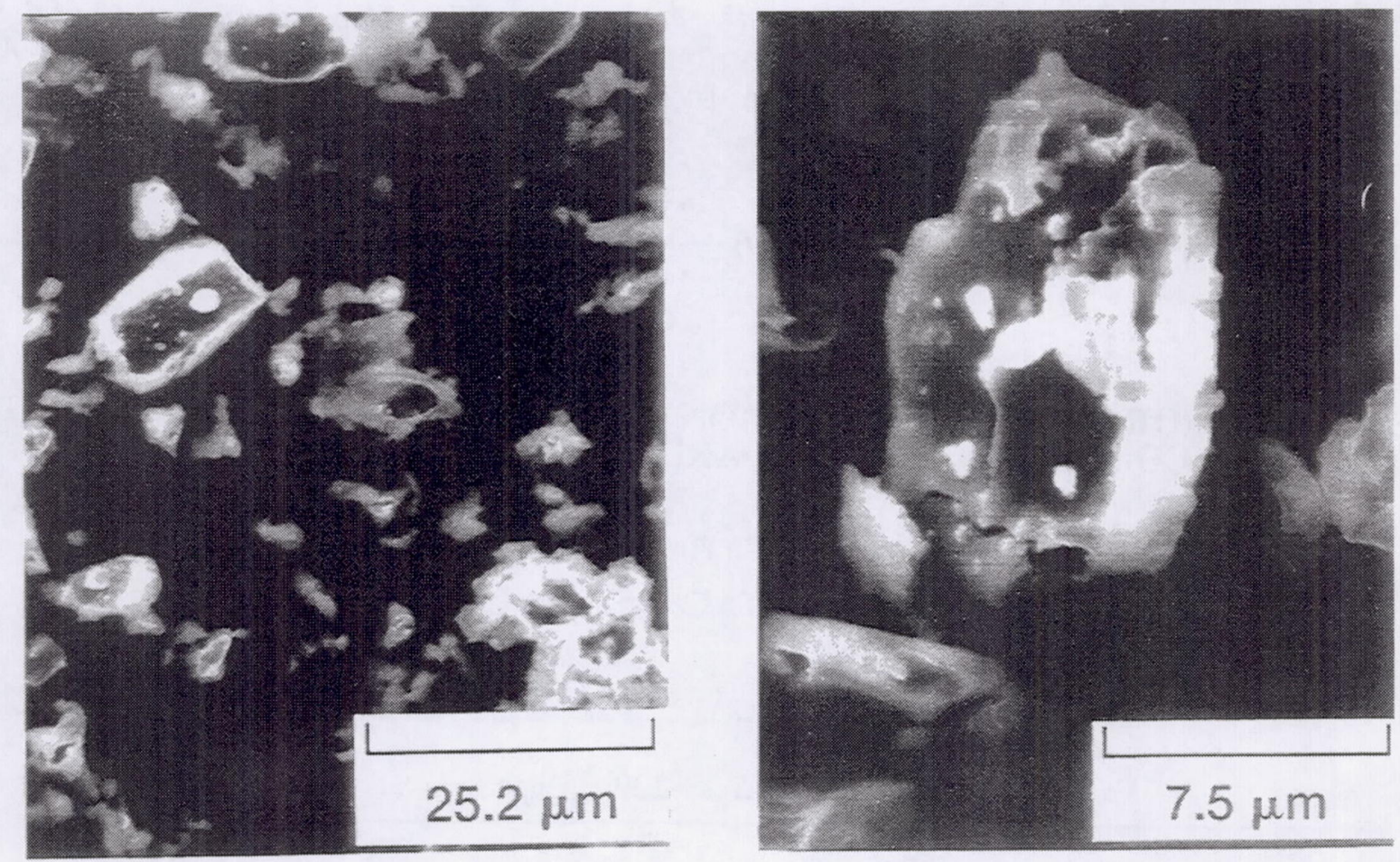

Figure 2. Scanning electron micrograph of sample R9 at two levels of magnification showing range of grain sizes and the morphology of a typical platelet-shaped grain.

At this point, the mechanism and by-products of this reaction are not known. It is possible to write a balanced equation for the reaction (1):

$$
\left(\mathrm{C}_{5} \mathrm{H}_{5}\right)_{3} \mathrm{In}+2 \mathrm{Cu}_{2} \mathrm{Se}+3 \mathrm{~L} \underset{25^{\circ} \mathrm{C}}{\stackrel{4-\mathrm{Mepy}}{\longrightarrow}} \mathrm{CuInSe}_{2}+3 \mathrm{CpCu}(\mathrm{L})
$$

This metathesis reaction should produce insoluble $\mathrm{CuInSe}_{2}$ and an example of a well known complex [15] of the general formula $\left(\mathrm{C}_{5} \mathrm{H}_{5}\right) \mathrm{CuL}$, where $\mathrm{L}$ is a two-electron donor. There are several shortcomings with this proposed reaction. First, we have not isolated the brown byproduct. Second, as discussed above, the CuInSe 2 yield is a function of the Cp3In to $\mathrm{Cu}_{2} \mathrm{Se}$ ratio. Finally, the $\mathrm{Cu} / \mathrm{In}$ ratio in the product can vary [2] and appears to be a function of the metals ratio; at this point, we have not determined an optimal $\mathrm{Cu} / \mathrm{In}$ ratio. 
An alternative mechanism may be the dissolution of the selenide in the coordinating solvent and subsequent reaction with the organoindium compound. This chemistry has been observed for the dissolution of metals [16,17] and solid-state halides and chalcogenides [18], and is an important route to precursors to solid state materials [16]. Another reaction by-product may contain all of the elements needed to produce $\mathrm{CuInSe}_{2}$ by analogy to the production of $\mathrm{CuS}$ from a copper sulfur precursor [16]. Interestingly, we obtained the same CuS precursor as Rauchfuss et al. [16] by reaction of $\mathrm{S}_{8}$ with $\mathrm{Cu}_{2} \mathrm{~S}$ [19].

In an attempt to determine how general reaction (1) is, we attempted to synthesize $\mathrm{CuInS}_{2}$ by the same route. The reaction was not successful using the analogous conditions. Therefore in order to drive the reaction to the right, the reaction was done in the presence of 2 mercaptopyridine $\left(\mathrm{C}_{5} \mathrm{H}_{4}(\mathrm{SH}) \mathrm{N}, 2-\mathrm{SH}-\mathrm{Py}\right)$ in 4-MePy. The point of using this reagent is to complex the copper by-product and help drive the reaction to completion. Reaction (2) occurs in refluxing (4-MePy). Upon 24 hours of refluxing, a black solid was removed from a brown solution. Analysis by XRD confirmed the presence of $\mathrm{CuInS}_{2}$ but also rather large impurity peaks. We repeated reaction (1) in refluxing (4-MePy) at $140^{\circ} \mathrm{C}$, to improve the quality of the material produced, the XRD peaks were sharper but there was still some crystalline impurity. A summary of $\mathrm{x}$-ray data for samples produced at $140^{\circ} \mathrm{C}$ is given in table 1 .

$$
\left(\mathrm{C}_{5} \mathrm{H}_{5}\right)_{3} \mathrm{In}+2 \mathrm{Cu}_{2} \mathrm{~S}+3(2-\mathrm{SH}-\mathrm{Py}) \underset{140^{\circ} \mathrm{C}}{\stackrel{4-\mathrm{Mepy}}{\longrightarrow}} \mathrm{CuInS}_{2}+3 \mathrm{CpCu}(2-\mathrm{SH}-\mathrm{Py})
$$

\title{
Table I. MAJOR X-RAY DIFFRACTION PEAKS FOR SAMPLES PREPARED AT $140^{\circ} \mathrm{C}$ COMPARED TO STANDARD (JC-PDS) DIFFRACTION PEAKS
}

\author{
Listing of d Spacings ( $\AA$ ) (Intensities Compared to Most Intense Peak) \\ For Experimental $\left(140^{\circ} \mathrm{C}\right)$ Compared to Literature (JC-PDS) Values for: \\ $\mathrm{CuInSe}_{2} \quad \mathrm{CuInS}_{2}$
}

hkl Experimental JC-PDS 23-209 Experimental JC-PDS 38-777

$\begin{array}{lllll}112 & 3.354(78) & 3.34(70) & 3.211(100) & 3.16(100) \\ 204,220 & 2.04(100) & 2.04(100) & 1.949(69) & 1.94(80) \\ 116,312 & 1.744(48) & 1.743(85) & 1.668(50) & 1.66(60) \\ 224 & 1.434(37) & 1.446(25) & 1.604(35) & 1.59(10) \\ 316,332 & 1.326(32) & 1.327(25) & 1.265(33) & 1.265(30)\end{array}$

As mentioned in the introduction, conventional bulk synthesis or thin-film processing typically occurs at temperatures above $400^{\circ} \mathrm{C}$, examples include direct reaction of the elements $\left(1150^{\circ} \mathrm{C}\right)$ [20], or reaction of $\mathrm{H}_{2} \mathrm{Se}$ with deposited thin films of metals $\left(450^{\circ} \mathrm{C}\right)[2,6,7]$. Other methods include microwave synthesis [21], spray pyrolysis $\left(250^{\circ} \mathrm{C}\right)$ [22], electrodeposition $(25$ $\left.{ }^{\circ} \mathrm{C}\right)$ [23] and reaction of a mixture of $\mathrm{Cu}$ and In polyselenides with alkylphosphines or $\mathrm{KCN}$ $\left(65^{\circ} \mathrm{C}-185^{\circ} \mathrm{C}\right)$ [24]. There are several recently reports of single-molecule chemical precursors that may be suitable for CVD. Decomposition of thiolate-bridged (-SR-) $\mathrm{In}-\mathrm{Cu}$ dimer precursors occurs below $350^{\circ} \mathrm{C}$ to produce $\mathrm{CuInQ}_{2}(\mathrm{Q}=\mathrm{S},[25] ; \mathrm{Q}=\mathrm{S}$ or $\mathrm{Se}[26])$. Deposition of thinfilms with these precursors must be done at higher temperatures (near $450^{\circ} \mathrm{C}$ ) to achieve 
acceptable films [26]. In summary, all of these alternative methods must be developed further to be practical for preparation of solar cell arrays on polymer substrates because of the temperature regimes required, lack of stoichiometry control, or use of destructive environments.

One measure of the utility of a chemical approach may be made by comparison to a recently reported rapid thermal processing technique using deposited thin films of In, $\mathrm{Cu}$, and $\mathrm{Se}$. In this process, the ternary compound was formed at temperatures between $500^{\circ} \mathrm{C}$ and $700{ }^{\circ} \mathrm{C}$; however, the substrate was maintained at a temperature above the melting point of indium ( 225 ${ }^{\circ} \mathrm{C}$ ) [9]. As this process maintains a fairly low substrate temperature using only the elements as precursors, a competing chemical approach must be able to produce the ternary at lower temperatures, below the decomposition temperature of a substrate with a minimum of impurity with maximum metal stoichiometry and phase control. Our current efforts are focused on a complete elucidation of the products of this reaction, its mechanism, and its generality and the possible isolation of precursor molecules that produce $\mathrm{CuInQ}_{2}$ at low temperature.

\section{CONCLUSIONS}

We have discovered a novel two-phase synthesis of $\mathrm{CuInSe}_{2}$ at $25^{\circ} \mathrm{C}$ from $\mathrm{Cu}_{2} \mathrm{Se}$ and $\mathrm{Cp}_{3}$ In in 4-methylpyridine. Characterization of the material produced shows it to be plateletshaped crystallites with an average particle size of $10 \mathrm{~mm}$, less than $2 \% \mathrm{C}$ and $\mathrm{H}$, with a small amount of unidentified crystalline impurity. Our results demonstrate that it is possible to produce from solution a material that is ordinarily synthesized in bulk or films at much higher temperatures or using extraneous reagents and/or electrons. A further point of interest is the use of a solid state reagent as a starting material that is converted to another solid state material by an organometallic compound. This chemistry has tremendous potential to produce precursors for a wide range of solid state materials of interest to the electronics, defense, and aerospace communities. Our results are significant not only for the potential low-temperature production of solid state materials and use of solid-state materials in chemical synthesis, but also because they stimulate the search for low-temperature precursors to an important class of electronic materials.

\section{ACKNOWLEDGEMENTS}

A.F.H. (NASA Lewis Director's Discretionary Fund), M.T.A. (National Research Council/NASA Lewis Research Center Associateship) and C.C.L. (NASA Grant NGT-50942) acknowledge financial support from Lewis Research Center We thank Ms. Ruth Cipcic of NASA LeRC (XRD) for technical assistance. We thank Dr. Bulent Basol, International Solar Electric Technology (ISET), for helpful discussions and preprints of his work.

\section{REFERENCES}

1. J. Woodyard and G.A. Landis, Solar Cells 31, 297 (1991).

2. L.L. Kazmerski and S. Wagner, in Current Topics in Photovoltaics, edited by T. J. Coutts and J. D. Meakin (Academic Press, London, 1985) pp. 41-109.

3. J.L. Shay, S. Wagner, and H.M. Kasper, Appl. Phys. Lett. 27, 89 (1975).

4. L.L. Kazmerski, M.S. Ayyagari, G.A. Sanborn, F.R. White, and A.J. Merrill, Thin Solid Films 37, 323 (1976).

5. G.A. Landis and A.F. Hepp, in Proceedings of the European Space Power Conference, ESA SP-320, Vol. 1, edited by J.J. Hunt (European Space Agency, Noordwijk, The Netherlands, 1991) pp. 511-522. 
6. R.A. Mickelsen, W.S. Chen, B.J. Stanbery, H. Dursch, J.M. Stewart, Y.R. Hsiao, and W. Devaney, in Proceedings of the 18th IEEE Photovoltaics Specialist Conference, Vol. II, (Institute of Electrical and Electronic Engineers, New York, 1985) pp. 1069 - 1073.

7. K. Zweibel, H.S. Ullal, and R.L. Mitchell, in Proceedings of the 21st IEEE Photovoltaics Specialist Conference, Vol. I, (Institute of Electrical and Electronic Engineers, New York, 1990) pp. 458-466.

8. B.M. Basol, V.K. Kapur, A. Halani, and C. Leidholm, Solar Energy Materials and Solar Cells 29, 163 (1993).

9. G.D. Mooney, A.M. Hermann, J.R. Tuttle, D.S. Albin, and R. Noufi, Appl. Phys. Lett. 58, 2678 (1991).

10. J.R. Tuttle, D.S. Albin, and R. Noufi, Solar Cells 30, 21 (1991).

11. P.D. Moskowitz and V.M. Fthenakis, Solar Cells 30, 89 (1991).

12. G.A. Landis and M.A. Perino, in Space Manufacturing 7 Space Resources To Improve Life On Earth, edited by B. Faughnan and G. Maryniak, (Amercian Institute of Aeronautics and Astronautics, Washington, D.C., 1989) pp. 144-151.

13. J.S. Poland and D.G. Tuck, J. Organomet. Chem. 42, 307 (1972).

14. A.F. Hepp, M.T. Andras, S.G. Bailey, and S.A. Duraj, Adv. Mater. Opt. Elec. 1, 99 (1992).

15. M.J. Hampden-Smith, T.J. Kodas, M. Paffett, J.D. Farr, H.-K. Shin, Chem. Mater. 2, 636 (1990), and references therein.

16. E. Ramli, T.B. Rauchfuss, and C.L. Stern, J. Am. Chem. Soc. 112, 4043 (1990).

17. S. Dev, E. Ramli, T.B. Rauchfuss, and S.R. Wilson, Inorg. Chem. 30, 2514 (1991).

18. S.C. Lee and R.H. Holm, Angew. Chem. Int. Ed. Engl. 29, 840 (1990).

19. A.F. Hepp, W.E. Eckles, S.A. Duraj, M.T. Andras, P.E. Fanwick, R.M. Richman, M.L. Sabat, M.B. Power, E.M. Gordon, and A.R. Barron, Covlent Ceramics II: NonOxides, edited by A.R. Barron, G.S. Fischman, M.A. Fury, and A.F. Hepp (Mater. Res. Soc. Proc. 000, Pittsburgh, PA, 1994) pp. 999-999.

20. T.L. Chu, S.S. Chu, C.P. Chien, and D.H. Lo, J. Electrochem. Soc. 132, 2020 (1985).

21. C.C. Landry and A.R. Barron, Science 260, 1653 (1993).

22. B.J. Brown and C.W. Bates, J. Appl. Phys. 68, 2517 (1990).

23. S. Moorthy Babu, R. Dhanasekaran, and P. Ramasamy, Thin Solid Films 198, (1991).

24. S. Dhingra, K.-W. Kim, and M.G. Kanatzidis, in Chemical Perspectives of Microelectronic Materials II, edited by L.V. Interrante, K.F. Jensen, L.H. Dubois, and M.E. Gross, (Mater. Res. Soc. Proc. 204, Pittsburgh, PA, 1991) pp. 163-168.

25. R. Nomura, S. Seki, and H. Matsuda, J. Mater. Chem. 2, 765 (1992).

26. W. Hirpo, S. Dhingra, A. Sutorik, and M.G. Kanatzidis, J. Am. Chem. Soc. 115, 1597 (1993). 
Public reporting burden for this collection of information is estimated to average 1 hour per response, including the time for reviewing instructions, searching existing data sources, gathering and maintaining the data needed, and completing and reviewing the collection of information. Send comments regarding this burden estimate or any other aspect of this collection of information, including suggestions for reducing this burden, to Washington Headquarters Services, Directorate for Information Operations and Re

\begin{tabular}{|l|l|l|}
\hline 1. AGENCY USE ONLY (Leave blank) & $\begin{array}{c}\text { 2. REPORT DATE } \\
\text { July } 1994\end{array}$ & $\begin{array}{r}\text { 3. REPORT TYPE AND DATES COVERED } \\
\text { Technical Memorandum }\end{array}$ \\
\hline
\end{tabular}

\section{TITLE AND SUBTITLE}

Room-Temperature Synthesis of $\mathrm{CuInQ}_{2}(\mathrm{Q}=\mathrm{S}$ or $\mathrm{Se})$ in Non-Aqueous Solution Using an Organoindium Reagent
5. FUNDING NUMBERS

WU-233-01-0A

\section{AUTHOR(S)}

Aloysius F. Hepp, Maria T. Andras, Christopher C. Landry, and Andrew R. Barron

7. PERFORMING ORGANIZATION NAME(S) AND ADDRESS(ES) REPORT NUMBER

National Aeronautics and Space Administration

Lewis Research Center

Cleveland, Ohio 44135-3191

E-8717

9. SPONSORING/MONITORING AGENCY NAME(S) AND ADDRESS(ES)

10. SPONSORING/MONITORING AGENCY REPORT NUMBER

National Aeronautics and Space Administration

Washington, D.C. 20546-0001

NASA TM-106557

11. SUPPLEMENTARY NOTES

Prepared for the Fall Meeting sponsored by the Materials Research Society, Boston, Massachusetts, November 29-December 3, 1993. Aloysius F. Hepp, NASA Lewis Research Center; Maria T. Andras, National Research Council-NASA Research Associate at the Lewis Research Center; Christopher C. Landry and Andrew R. Barron, Department of Chemistry, Harvard University, Cambridge, Massachusetts 02138. Responsible person, Aloysius F. Hepp, organization code 5410, (216) 433-3835.

12a. DISTRIBUTION/AVAILABILITY STATEMENT

12b. DISTRIBUTION CODE

Unclassified - Unlimited

Subject Category 23

13. ABSTRACT (Maximum 200 words)

We have discovered a novel two-phase synthesis of $\mathrm{CuInSe}_{2}$ at $25^{\circ} \mathrm{C}$ from $\mathrm{Cu}_{2} \mathrm{Se}$ and $\left(\mathrm{C}_{5} \mathrm{H}_{5}\right)_{3} \mathrm{In}$ in 4-methylpyridine (4-MePy). An analogous reaction to produce $\mathrm{CuInS}_{2}$ must be run at $140^{\circ} \mathrm{C}$ in refluxing $4-\mathrm{MePy}$ in the presence of 2-mercaptopyridine. Microscopy of CuInSe ${ }_{2}$ produced at $25^{\circ} \mathrm{C}$ shows it to be platelet-shaped crystallites with an approximate particle size of 10 microns, less than $2 \% \mathrm{C}$ and $\mathrm{H}$, with a small amount of unidentified crystalline impurity. Our results demonstrate that it is possible to produce from solution a material that is ordinarily synthesized in bulk or films at much higher temperatures or using extraneous reagents and/or electrons.

14. SUBJECT TERMS

Synthesis; Copper indium diselenide; Microscopy

17. SECURITY CLASSIFICATION OF REPORT Unclassified
18. SECURITY CLASSIFICATION OF THIS PAGE Unclassified
19. SECURITY CLASSIFICATION OF ABSTRACT Unclassified 